\title{
O PENSAMENTO NO PERÍODO EDO (1603-1868)
}

Madalena Natsuko Hashimoto Cordaro

RESUMO: Tentando rastrear as idéias (neo)confucionistas que se diz permearem todo o período Edo, o presente estudo se concentra nos Estudos Confucionistas (Jugaku), nos Estudos Clássicos (Kogaku), nos Estudos Vernaculares (Kokugaku) e nos Estudos do Coração (Shingaku), sem diferenciar filosofia de religião, mas atento tanto à diversidade dos enfoques em diferentes momentos históricos e grupos sociais, quanto ao processo de amálgama dessas idéias que se processaram no Japão. Analisa-se principalmente o conflito giri-ninjô (obrigação-sentimento humano), tão presente em obras literárias do período e na sociedade como um todo, à luz das conclusões às quais se chegou.

ABSTRACT: In an attempt to define (neo)confucianist ideas which are known to permeate Edo period, this essay deals with Confucianist Studies (Jugaku), Classic Studies (Kogaku), Vernacular Studies (Kokugaku) and Heart Studies (Shingaku), with no discrimination between philosophy and religion, but aware of the diversity of approaches in different historical moments and social classes, as well as of those ideas transformation processed in Japan. It is analised mainly the giri-ninjô (obligation-human feelings) conflict, which is so abundant in literary pieces of the time and in the society as a whole, under the essay conclusions point of view.

PALAVRAS-CHAVE: Estudos Confucionistas; Estudos Clássicos; Estudos Vernaculares; Estudos do Coração; conflito giri-ninjô (obrigação-sentimento humano).

KEYWORDS: Confucianist Studies; Classic Studies; Vernacular Studies; Heart Studies; giri-ninjô conflict. 
Tentar discriminar o pensamento entre filosofia e religião é em todo caso uma tarefa inglória e na cultura japonesa os constantes empréstimos entre elas inibem qualquer iniciativa. Assim, se considerarmos o xintoísmo em seu aspecto religioso, poderemos notar que este se encontra em um estágio intermediário entre culto e seita, através de cultos a deidades tais como Jizô ou Inari, de festividades anuais de agradecimento e cerimônias agrícolas e de centros de templos de confraternidades tais como Ise e Izumo; no entanto, na passagem para o período Meiji, o xintoísmo foi utilizado como uma justificativa ideológica da ascendência divina do imperador que intensificou os movimentos contrários ao xogunato. Tomaram-se emprestados muitos sistemas de pensamento do continente conforme as necessidades de momentos variados. Assim, o confucionismo e o xintoísmo se valeram dos métodos de meditação e conceitos da metafísica budista, o budismo e o xintoísmo utilizaram certa ética confucionista, o budismo e o confucionismo foram totalmente japonizados ${ }^{\prime}$ em vários momentos de sua história.

Numa primeira aproximação ao estudo do pensamento do período Edo (16031868) nota-se que o neoconfucionismo é o sistema filosófico mais citado, devido a seu dito caráter oficial como porta-voz do xogunato em sua justificativa de adoção de determinadas medidas morais. Como tal, tratar-se-ia de um sistema ortodoxo, autoritário e retrógrado. No entanto, estudos mais recentes têm mostrado que esse caráter oficial entre os intelectuais confucionistas e o xogunato não teria sido tão claro e nem tão permanente quanto se apregoava. $\mathrm{O}$ estudioso Herman $\mathrm{Ooms}^{2}$, com efeito, defende a posição de que membros da família Hayashi, ansiosos por estabelecerem eles mesmos uma hegemonia no assunto e um prestígio duradouro, teriam sido os responsáveis pela versão de que teriam existido laços emblemáticos entre o xôgum Tokugawa Ieyasu, Fujiwara Seika (1561-1619), o neoconfucionismo e Hayashi Razan (1583-1657), defendendo a ficção de uma ortodoxia apoiada pelo xogunato, a qual se teria tornado importante nos anos de 1650 a 1660 . Ooms defende sua hipótese citando para tanto o fato de que, durante as três primeiras gerações, os Tokugawa financiaram a construção do complexo de Nikkô, templo xintoísta em memória a Ieyasu, o grande fundador da dinastia, em 500.000 ryo $\hat{o}^{3}$; a reconstrução e reforma dos templos de Ise num montante equivalente; mas apenas contribuíram com uma ajuda simbólica, 200 ryô, quando do

1. Sobre os estudos enfocando o pensamento no Período Edo, é muito instrutivo o artigo de Samuel Hideo Yamashita, "Reading the New Tokugawa Intellectual Histories", in The Journal of Japanese Studies, vol. 22, n. 1, Seattle, University of Washington, 1996, onde o autor analisa a historiografia em língua inglesa, subdividindo-a em quatro grupos: o da teoria da modernização, que tenta explicar Edo para chegar a Meiji, incluindo Bellah, Rubinger e Nakai: o grupo de Bary, que situa o neoconfucionismo num panorama diverso, dinâmico e em mutação, incluindo também Tucker e Nosco; os novos intelectuais que se inspiram em histórias intelectuais enfatizando as periferias, incluindo Harootunian, Najita e Ooms e, finalmente, uma aproximação pós-moderna nos trabalhos de Naoki Sakai, onde desaparecem biografias de personalidades, famílias de pensamentos ou movimentos para se concentrar no discurso, nos "textos"

2. "Neo-Confucianism and the Formation of Early Tokugawa Ideology: Contours of a Problem" In Confucianism and Tokugawa Culture.

3. $R y \hat{o}$, medida monetária do período. A utilização de moedas cunhadas e a criação das cartas de crédito foram resultados da organização e do controle dos comerciantes. 
estabelecimento da academia confucionista de Razan. Assim mesmo, o discurso confucionista demorou cerca de cem anos para amadurecer, de 1570 a 1650, e foi de especial importância o período entre 1666 a 1728, ou seja, o primeiro período, centralizado em Kamigata, quando um grande número de pensadores japoneses se confrontou com a vastidão dos ensinamentos chineses de vertente confucionista.

Aceitando-se que o neoconfucionismo foi uma ortodoxia dos Tokugawa, mesmo assim, diferiu sobremodo da ortodoxia forçada que foi na dinastia Ming (1368-1662) da China: com efeito, tratou-se mais, no dizer de Ooms, de um padrão negativo de ortodoxia. Com a supressão de ensinamentos ou atividades de grupos não desejáveis, nos chamados kakure, "ocultos", seja cristãos, seja seguidores da seita do nenbutsu, de budistas nichiren ou fujufukuse, que se recusavam a se filiarem ao budismo ${ }^{4}$, tendo sido os dois últimos ligados à resistência campesina. Além disso, como chama a atenção o estudo de Kurozumi Makoto ${ }^{5}$, houve uma certa interpretação do período Edo do ponto de vista do estado imperial da era Meiji, que tendeu a ver em seu passado recente teorias fechadas, numa projeção reducionista que refletiu seus interesses políticos.

Posto portanto que o neoconfucionismo não foi o único sistema de pensamento do período Edo, é importante estudarmos os outros sistemas e relacioná-los entre si. Uma grande ebulição pôde ser sentida devido, principalmente, à divulgação do ensino, ao avanço das técnicas reprodutivas de livros e ao grande desenvolvimento urbano. Os intelectuais em sua maioria queriam de certa maneira chamar a atenção do xogunato e serem seus ideologistas: os Hayashi como porta-vozes oficiais da ortodoxia neoconfucionista; a seita budista Tendai que conseguiu ser escolhida como o culto oficial de Nikkô; Suzuki Shôsan $(1579-1655)^{6}$, que queria transformar a sua seita em única a ser aceita; e "o xogunato não se importou muito com os ensinamentos contidos nos diferentes sistemas, desde que não fossem transparentes"

O ensino se diversificou, não se limitando apenas à utilização do método de transmissão secreta de ensinamentos somente para os discípulos eleitos; informações e discussões passaram a ser difundidas em palestras públicas, escolas e academias particulares (shijuku) que se espalharam pelas metrópoles e províncias, as quais, ao proporcionarem alfabetização para além da básica para seus estudantes, fomentaram

4. $O$ fato de seguidores do cristianismo e do nenbutsu terem sido perseguidos e tidos como perigosos para o xogunato mostra a força da religião no campo político. Os fujufukuse, "não receber, não dar", recusaramse a se filiarem ao budismo oficial quando do shûmon-aratame no jô, de 1613, artifício encontrado para um maior controle da população. Os kakure renegaram a religião mas continuaram cristãos até que se revelaram na era Meiji quando da liberdade religiosa, tendo gerado um curioso sincretismo: Maria-sama é cultivada num butsudan e reverenciada como um kami.

5. Kurozumi Makoto, “The Nature of Eartly Tokugawa Confucianism", In The Journal of Japaneses Studies, vol. 20, n. 2, trad. Herman Ooms. 1994, pp. 347-348.

6. Autor de kanazôshi, livros populares escritos em silabário, ligado ao xogunato através de sua família, tornou-se monge em 1620.

7. "Neo-Confucianism and the Formation of Early Tokugawa Ideology: Contours of a Problem", p. 60. In Peter Nosco (ed.), Confucianism and Tokugawa Culture, New Jersey, Princeton University Press, 1984. Ooms lê os movimentos intelectuais do período Tokugawa sempre atento com as relações de poder por eles encobertos, utilizando-se livremente da religião, da mitificação, dos rituais e de todos os meios de legitimização a seu alcance. 
discussões mais amplas e propiciaram o surgimento de pensadores nas classes dos camponeses e dos comerciantes. Se num primeiro momento os instrutores eram samurais rônin e monges, com a ascendência econômica dos comerciantes, estes começam a se interessar por idéias outras que, ao fim, tentassem justificar sua própria identidade enquanto classe, como veremos na fundação e no patrocínio das academias Kaitokudô ${ }^{8}$ em Ôsaka e Kaihôdô em Edo, ou na presença marcante de camponeses junto a Ishida Baigan (1685-1744) e o movimento Shingaku', que foi uma das bandeiras para a Restauração Meiji, num movimento de revivescência do poder do imperador. Por outro lado, "não é exagero dizer que o estímulo ao pensamento e aprendizado no período Tokugawa deveu-se ao impacto intelectual, que se alastrava, do confucionismo e dos ensinamentos de Chu Hsi (1130-1200)"10, ou seja, mesmo as idéias que se lhes foram contrárias tiveram sua razão de existir por causa de sua introdução.

Uma outra visão sobre a história do pensamento no período Edo é a do estudioso Katô Shûichi, que associa não somente a produção intelectual mas também a artística à divisão de classes preconizada pelo xogunato. Assim, diferentemente da era anterior quando a expressão teatral sarugaku e a composição coletiva de poemas encadeados (renga) eram práticas de todas as classes, na sociedade dos samurais estes patrocinaram e consumiam uma cultura aristocrática, tais como o teatro nô, as obras pictórias da família Kanô, a composição de versos e prosa em língua chinesa, enquanto que as demais classes se caracterizavam pela absorção do teatro kabuki, da composição de ficção em língua japonesa coloquial publicada principalmente em silabário, de imagens da família de pintura Rinpa e de pintores anônimos de usos-e-costumes (fûzoku-ga) e do mundo-flutuante (ukiyo-e).

Os intelectuais, segundo o estudioso, se poderiam dividir em quatro grupos, de acordo com os diferentes papéis que exerceram. O primeiro seria o dos intelectuais e estudiosos oficiais (goyô gakusha), que haviam servido ao xogunato, tais como o monge zenbudista Sûden (1569-1633), o monge da seita Tendai chamado Tenkai (1536?-1643), Fujiwara Seika, Ogyû Sorai e Hayashi Razan. O segundo grupo seria o dos intelectuais independentes, que serviram aos pequenos e médios samurais tais quais o monge zenbudista da seita rinzai Takuan (1573-1643) e o notório samurai sem mestre Miyamoto Musashi (1584-1645), o qual influenciou muito na concepção do bushidô (Caminho do Samurai). O terceiro grupo seria o dos intelectuais que iniciaram a expansão da ideologia a agricultores e comerciantes, entre os quais se encontrou Bankei Yôtaku (1622-93),

8. Sobre o assunto, ver Tetsuo Najita, Katokudô: Visions of Virtue in Tokugava Japan, Chiacago \& Londres, The University of Chicago Press, 1987. O autor estuda a academia e sua evolução histórica, traçando paralelos entre diferentes momentos e pensadores que por lá ensinaram, concluindo na formação de um sistema de pensamento que justificou a classe dos comerciantes, retirando seu estigma de classe improdutiva.

9. Sobre o assunto, ver Robert N. Bellah, Tokugawa Religion - The Cultural Roots of Modern Japan, New York, Londres, The Free Press, 1985 ( $1^{\mathrm{a}}$ ed., 1957). Como o subtítulo da obra indica, o autor se preocupa em tentar traçar as raízes culturais de um certo Japão, o do pós-guerra, não tendo sido sempre tão distanciado de seu objeto de estudo quanto talvez o devesse ter sido.

10. Kurozumi, op. cit., p. 345. Chu Hsi é também grafado como Zhu Xi no texto de Katô Shûichi. O filósofo chinês é referido no Japão como Shushi, adaptação fonética ao idioma. Shushi, da dinastia Sô, foi um escritor prolífico e influente; sua obra completa se compõe de 140 volumes. 
que tinha também relações com o movimento Shingaku, do qual trataremos a seguir. $O$ quarto grupo seria o dos intelectuais que se haviam retirado do mundo, não almejando serem conectados com nenhuma classe em particular, seguindo a tradição medieval da literatura inja dos retirados, tais como Ishikawa Jôken (1583-1672), atitude que ecoará no movimento dos pintores literatos bunjin.

A classificação de Katô é de fato muito elucidativa no sentido de separação dos mundos distintos das diferentes classes sociais e, embora concorde, a nosso ver, com a afirmação de que o período Edo foi neoconfucionista em sua essência - a diferentes classes sociais corresponderia diferentes mundos culturais -, problematiza a questão. Assim, entrevêem-se nuances contrárias à hegemonia do confucionismo, tais como quando cita a sobrevivência marcante da tradição, na figura dos inja, de poetas tais como Bashô, de pintores ligados ao círculo de Kôetsu, ou da coexistência com o budismo (Shingaku) e o xintoísmo (Kokugaku). Nosso tratamento das idéias do período visará não exatamente o público ao qual se dirigiram ou o grupo produtor mas privilegiaremos o teor dos pensamentos debatidos e defendidos pelos estudiosos, numa tentativa de formar uma visão da complexidade de sua formação, como veremos a seguir.

\section{Jugaku ou Estudos Confucionistas}

A afirmação corrente de que o neoconfucionismo proporcionou ao xogunato sua legitimidade intelectual não correspondeu inteiramente à verdade, embora muitos de seus valores éticos e morais, a maioria deles em processo avançado de aculturação, tivessem sido incorporados na vida cotidiana da população urbana, muitas vezes de modo apenas aparente, assim refletidos nas obras literárias e visuais e, principalmente, nas representações do teatro jôruri e kabuki.

A doutrina neoconfucionista da dinastia Sung (960-1126), preconizada pelos ensinamentos do pensador chinês Chu Hsi, foi introduzida pelos monges zen da seita rinzai (pois que a doutrina zen foi também material utilizado em sua construção teórica, no que tange a dimensões espirituais e de desenvolvimento individual do kokoro, mente/ coração) durante o período Ashikaga (século XIV-XVI), mas não frutificou, tendo permanecido à sombra do budismo, em relação ao qual era muito racional. Mas no século XVII espraiou-se para além de seus limites monásticos, tendo Ieyasu contratado um discípulo de Chu Hsi para trabalhar em sua cúpula, em 1605. Fujiwara Seika (15611619) e o conselheiro oficial Hayashi Razan" (1583-1657) serviram Ieyasu em assuntos legais e históricos.

Se o xogunato se iniciou como um governo militar, com a pax Tokugawa instaurada, transformou-se em uma instituição civil, sendo que muitos samurais começaram a

11. Razan, samurai descendente dos Fujiwara e discípulo de Seika, trabalhou como oficial no governo de Ieyasu, tendo-se retirado da vida pública e se tornado monge, o que mostra a coexistência do confucionismo com o budismo. Devemos citar, no entanto, que o fato de se tornar monge, muitas vezes, não tinha relação direta com a religião budista em profundidade e sim com um desligamento total de atividades mundanas e/ou pressupunha uma maior dedicação aos estudos. 
desempenhar funções burocráticas, notadamente a partir do quarto xôgum, Tokugawa Ietsuna (1641-80), enfatizando mais as artes literárias e as virtudes confucionistas. Hayashi Razan lecionou tanto a Ietsuna quanto a Iemitsu e Yamazaki Anzai (16181682) foi conselheiro de Hoshina Masayuki (regente de 1651 a 1669 durante o governo de Ietsuna), fazendo com que o pensamento neoconfucionista se tornasse o argumento por excelência de justificativa do monopólio das funções políticas por parte do xogunato ${ }^{12}$. Contra-argumenta Kurozumi lembrando que, mesmo que o confucionismo estivesse sendo utilizado em sua veia de experimentação administrativa, isso não significou que se tivesse estabelecido como monopólio no campo geral do pensamento, lembrando também "o classicismo, uma certa visão nostálgica do mundo da corte imperial e elementos nativistas que instigaram o mundo intelectual"13.

O fato de Fujiwara Seika ter sido muito tolerante e aberto em relação às várias tradições dos "Ensinamentos Chineses" e ter reverenciado o eclético da dinastia Ming, Lin Chao-en (1517-98), seu contemporâneo que trabalhava num sistema de unidade dos três caminhos (confucionismo, budismo e taoísmo), mostra que o confucionismo do início da era Edo era indiscriminado, inclusivo e dependente de predileções especiais dos pensadores ${ }^{14}$. Assim, ao neoconfucionismo de quatrocentos anos de idade se soma o "velho" confucionismo de dez séculos anteriores com toda sua variedade de aspectos. Em seu tempo, o confucionismo não era ainda o pensamento mais influente. Afirma Katô Shûichi que "nem todos os intelectuais oficiais foram oportunistas, mas no caso de Razan é difícil negar a acusação" 15 , lembrando justamente que a popularidade mesma do confucionismo muito deveu a esse seu caráter inteligente e oportunista.

Em 1630, Hayashi Razan fundou uma escola em Edo que foi a universidade confucionista oficial, habilmente administrada, centralizada na conduta e nas obrigações que os homens têm entre si num dado momento presente. As cinco relações humanas básicas seriam as entre pais e filhos, senhores e servidores, marido e mulher, irmão mais velho e mais novo, entre amigos. Mas se na China a primeira virtude era a piedade filial ( $k \hat{o}$, a relação de obediência e reverência dos filhos para com os pais), no Japão a ênfase foi atribuída à segunda virtude, a da lealdade (chû, a relação de obediência, reverência e dedicação total dos protegidos em relação a seus protetores), de acordo com os interesses xogunais.

A virtude da lealdade entre samurais e seus senhores, entre esses senhores e a elite guerreira do xogunato Tokugawa, e a concepção de iemoto pode ser sentida nas várias instituições durante o período Edo. Assim, as chamadas "escolas" ou "famílias" de pintura ${ }^{16}$ seguiam também uma organização centralizada e hierárquica, como pode

12. Conrad D. Totman, Politics in The Tokugawa Xogunato 1600-1843, Cambridge, Massachusetts, Harvard University Press, 1967, p. 249.

13. Kurozuni, op. cit., p. 340.

14. Idem, p. 343.

15. História da Literatura Japonesa, vol. 2, p. 21.

16. O sufixo - ha (tendência, grupo, princípio, ismo) é o mais comum quando ligada a organizações nas artes plásticas, sendo $0-z a$ ligado ao teatro e aos grupos de poetas, -ryû aos estilos de arranjos florais. À falta de termo mais específico, utilizo "família", já que a transmissão de "segredos" de cada linha artística era tido como fundamental na passagem de geração a geração. 
ser observado no desenvolvimento da família de pintura Kanô, que serviu os governantes militares e chegou a se constituir de quatro casas principais e doze secundárias, tendo dominado a produção visual a serviço dos militares e sido muito influente (Hishikawa Moronobu, primeiro pintor conhecido do ukiyo-e, foi a um tempo aprendiz numa oficina Kanô), mas não foi um monopólio geral, como podemos notar na permanência e evolução de outras famílias artísticas em vários campos, principalmente voltadas para o público dos citadinos.

O estudioso Edwin O. Reischauer ${ }^{17}$ apontou bem a tensão que o neoconfucionismo enfrentou, no sentido em que enfatizava a ordem civil, imperial e centralizada, mas baseava-se na hegemonia militar; prezava relações burocráticas no governo, o aprendizado individual e a excelência moral, mas baseava-se em relações pessoais de lealdade e na hereditariedade. Dessas tensões, acredita o estudioso, originou-se um resultado criativo no reconhecimento do mérito pessoal como também no status familiar que persistem até hoje. Aliado a isto, vemos que o neoconfucionismo não foi o único sistema filosófico, ou "Caminho", ou "Ensinamentos", do xogunato Tokugawa, questionando-se até sua importância central, pois elementos xintoístas e budistas, tais como podemos notar no processo de mitificação de Ieyasu, penetraram fortemente em sua formulação, embora os intelectuais neoconfucionistas tivessem enfatizado a natureza fundamental de seu "Caminho" ("Caminho dos Homens"), justificando um pragmatismo social superior pela ética defendida em seus ensinamentos.

Kaibara Ekken (1630-1714), oriundo da região noroeste de Kyûshû, popularizou essas idéias escrevendo no idioma japonês - fator importante no processo de japonização - e transformou o neoconfucionismo em ciência moral; ensinando que todos os seres humanos, incluindo-se os camponeses, possuem a capacidade reverencial de conhecer as coisas objetivas, ordená-las de um modo com princípios e de melhorar a vida à sua volta. A mensagem aos camponeses - Kaibara dedicou-se aos estudos agrônomos ${ }^{18} \mathrm{e} \mathrm{à}$ ética a eles relacionada - é de não esperar a assistência benevolente dos administradores dos domínios de cima para baixo mas de agarrar o conhecimento ante eles para nutrir a vida, presente da natureza. Ekken combinou elementos cosmológicos confucionistas e xintoístas, amalgamando "um conceito neoconfucionista chinês de naturalismo" e "uma sensibilidade nativa xintoísta que simultaneamente celebraram a fecundidade da natureza" ${ }^{\prime \prime}$. As inovações que Ekken introduziu no sistema bem demonstram que houve uma japonização e não somente um processo de replicação das idéias de confucionistas chineses da dinastia Ming (1368-1644) ou coreanas da dinastia Yi (1392-1909): "a maior tarefa dos neoconfucionistas do período Tokugawa foi definir o Caminho em termos japoneses e evocar o modelo de sábio para seu próprio período", adaptando-os

17. "Tokugawa Japan: A Centralized Feudal State". In East Asia: Tradition and Transformation, Londres, Harvard University, 1973.

18. Sua obra Yamato Honsô (Plantas do Japão), de 1708, compõe-se de 23 volumes de texto e 2 de ilustrações, contendo mais de 1.300 espécies de plantas e árvores e marcou uma nova era nos estudos japoneses de história natural.

19. Mary Evelyn Tucker, "Moral and Spiritual Cultivation", Japanese Neo-Confucianism: The Life and Thought of Kaibara Ekken (1630-1714), Albany, State University of New York Press, 1989, pp. 81 e 59. Citado em Yamashita, "Reading the New Tokugawa Intellectual Histories" 
ao "tempo, espaço e circunstâncias e portanto tornando-os apropriados ao contexto japonês" ${ }^{20}$. Suas idéias atingiram camponeses e citadinos, entre eles o escritor Nishikawa Joken que escreveu Chônin Bukuro (Saco de Comerciantes, 1719) e Hyakushô Bukuro (Saco de Camponeses, 1721), onde se encontram comentários sobre moralidade, natureza, política, sociedade, história, língua e costumes, numa linguagem acessível, com poucos ideogramas.

Entre outros estudiosos samurais que seguiram outras linhas, pode-se citar Nakae Tôju (1606-1648), que se inclinava à escola idealista do confucionista Ming Wang Yang-ming ${ }^{21}$ (1472-1529), alto-oficial que foi mais à frente do que a ortodoxia de Chu Hsi, advogando tanto a iluminação espiritual através de um auto-exame meditativo e de um ativismo ético vigoroso na sociedade. A ênfase de Wang Yang-ming no senso moral intuitivo, na disciplina pessoal, nas ações mais do que nas palavras, apelou para os samurais, que encontraram neles ecos do período Ashikaga quando da influência do zenbudismo. De acordo com a análise de John K. Fairbank ${ }^{22}$, Wang Yang-ming "negava o dualismo do sistema de Chu Hsi", a distinção clara entre o Paraíso e o Homem (portanto entre o princípio do Paraíso versus o desejo humano), enfatizava a meditação e o conhecimento intuitivo (o que o aproximava do zenbudismo), e também a "unidade do conhecimento e da conduta". dizendo que "o conhecimento é o começo da conduta" e que "a conduta é o complemento do conhecimento"

Também dentro do neoconfucionismo se desenvolveu um processo de sacralização gradual dos elementos constitutivos da nova estrutura de dominação, um processo perceptivamente xintoísta: primeiramente os líderes (lembre-se Nikkô ${ }^{23}$ ), depois a classe dirigente e a própria estrutura hierárquica da sociedade e finalmente até aos dominados são atribuídos significação cosmológica e religiosa através da apropriação de elementos de várias tradições, xintoísmo, budismo e teologias e cosmologias folclóricas.

Ainda dentro da chave confucionista devemos citar a escola Mito $^{24}$ centralizada em torno de Tokugawa Mitsukuni (1628-1700), a menor e menos autônoma das casas colaterais estabelecidas pelos outros filhos de Ieyasu, sendo as outras duas Owari e Kii. Exemplo de auto-abnegação, retidão e sentimento de missão a cumprir para proteger a casa Tokugawa, Mitsukuni comanda a compilação de uma grande obra, Dai-Nihon-shi (A Grande História do Japão), que durou de 1657 a 1720, tendo tido, à época de sua morte, uma equipe de 130 intelectuais engajados no projeto. Entre os estudiosos colocou sob sua proteção em 1665 um chinês confucionista, Chu Shun-shui (1600-82), exilado

20. Idem, pp. 28,81 .

21. Ôyômei, na transcrição fonética japonesa.

22. "State \& Society under the Ming". In East Asia: Tradition and Transformation. Londres \& New York, Harward University, 1973, pp. 192-193.

23. Nikkô significa "raios de sol", "brilho solar", e o título outorgado ao templo pelo imperador foi Tôshôgû, "templo do Deus Sol do Leste" A identificação xintoísta veio através do sincretismo budista, onde deidades nativas seriam manifestações do Buda cósmico. Ieyasu tomou-se então o Deus Sol (Dainichi) e o Buda, Sol do Leste.

24. Sobre o assunto ver Kate Wildman Nakai, "Tokugawa Confucian Historiography: The Hayashi, Early Mito School and Arai Hakuseki". In Peter Nosco (ed.), Confucianism and Tokugawa Culture, New Jersey, Princeton University Press, 1984. 
então em situação pobre e instável em Nagasaki, que difundiu o confucionismo e ajudou a iniciar o movimento intelectual Kogaku ${ }^{25}$. Em 1666, Mitsukuni eliminou 3.088 templos budistas e iniciou a restauração de templos xintoístas. Suas diretrizes afinavam com as idéias dos Hayashi, ou seja, tratava-se de um debruçar sobre a história para legitimar a ordem Tokugawa e seus colaboradores interpretavam que o fato de redigir a grande história seria um meio de continuar a função demonstrativa entre xogunato e xôgum, utilizando para tanto as normas confucionistas, propondo um shôgun-den, historiografia biográfica dos xôgum à moda chinesa. A relação entre o xôgum e o imperador e a adoção de critérios da historiografia chinesa confucionista à substância da história japonesa resultariam na base da legitimidade política a partir da transferência da autoridade que o imperador outorgara ao xôgum Ieyasu através de seu título.

Arai Hakuseki (1657-1725), intelectual confucionista importante e conselheiro xogunal, liderou três conjuntos de reformas no período em que esteve a serviço do xogunato. $O$ primeiro foi uma série de reformas fiscais que incluíram restauração de valores monetários, reforço no controle do comércio exterior em Nagasaki e melhoramentos nos sistemas de estradas. Teve como objetivo intervenções xogunais em favòr do bem-estar da população, numa imagem política "cálida e compadecida", que se seguiu aos protestos de camponeses em Echigo. Hakuseki quis remodelar o xôgum como um sábio e um verdadeiro dirigente, tentando mascarar sua subordinação implícita ao imperador.

Hakuseki, embora tenha sido, na opinião de historiadores da literatura japonesa, convencional e sem originalidade em seus escritos neoconfucionistas, o fez no idioma japonês e abarcou temas variados, tais como a história do Japão, a língua japonesa, vários estudos comparados e aspectos de geografia humana. Assim como Ogyû Sorai, foi "excepcional pela virtude de seu racionalismo e respeito pelos fatos, pela prosa lúcida, pela oposição a todos os tipos de mitificação e pela sua coragem intelectual como ser humano autônomo" ${ }^{26}$. Escreveu a primeira geografia mundial em japonês, Sairan Igen (1713, revisada em 1725 ${ }^{27}$ Seu trabalho mais importante foi no campo da história japonesa, onde se destacam três obras: Koshitsû (Conhecendo a História da Antigüidade) e Koshitsû Wakumon (Dialógos sobre Conhecendo a História da Antigüidade) e Tokushi Yoron (Teses sobre a História), onde desconsidera a Idade dos Deuses na criação da nação japonesa e trata apenas da ascensão e queda de famílias que tomaram o poder, ou seja, da história da transferência do poder da família imperial para famílias da aristocracia (a Fujiwara) até as recentes famílias de samurais (Ashikaga,

25. Ver Julia Ching, "Chu Shun-shui, 1600-82, A Chinese Scholar in Tokugawa Japan". In Monumenta Nippponica, vol. 30, n. 2, 1975, pp. 177-191. É interessante notar o fato de que o confucionismo é visto no Japão como filosofia moral mas sabe-se que Shun-shui realizava cerimônias sacrificiais de animais, denunciando sua origem chinesa. No Japão tal prática não existiu e já no início da introdução do confucionismo tal característica foi veementemente rejeitada.

26. Katô Shûichi, História da Literatura Japonesa, vol. 2, p. 76.

27. Composta de cinco volumes que tratam dos continentes, sendo a América do Sul e a África "locais onde quase ninguém vai" O extremo interesse pela geografia, biologia, ciências naturais e matemáticas vão ter seus reflexos na produção de uma obra visual riquíssima tematizando a natureza de modo exaustivo, entre os quais podemos citar a família Shijô, de Kyôto. 
Toyotomi, Tokugawa). Sua contribuição foi "estender a objetividade histórica e o pensamento racional aos limites do possível dentro das restrições de uma ditadura militar e da filosofia ortodoxa de Chu Hsi. Abriu, assim, caminho para o movimento Kokugaku (Estudos Vernaculares) e Yôgaku (Estudos Ocidentais)"28.

Os Estudos Confucionistas, portanto, se espalharam pelo Japão com rapidez e suscitaram um interesse profundo e amplo, tendo seu pensamento e vocabulário penetrado em várias áreas do saber. Hayashi Razan e Yamazaki Ansai tentaram criar novas teologias xintoístas utilizando estruturas neoconfucionistas; o aparecimento de sincretismos, a penetração de suas idéias na vida cotidiana dos citadinos e na literatura popular podem ser atestados como metáforas altamente carregadas de um conjunto complexo de identificações que incluíam o chinesismo em oposição ao japonesismo (kara-gokoro e yamato-gokoro), giri ou a preocupação com o comportamento moral social em oposição a ninjô ou sentimento humano, as piedades filiais, a lealdade cega aos protetores, a resignação às demandas do kokoro, a habilidade em oposição à hereditariedade.

Kurozumi em seu estudo sobre o confucionismo Tokugawa ${ }^{29}$ questiona a variante introduzida no Japão e o processo de indigenização de vários elementos-chave. Iniciandose com a total ausência de rituais confucionistas na vida de indivíduos e comunidades, tais quais o culto ao Paraíso (Ten) e aos ancestrais e do aparato burocrático como sistema de exames que funcionaram na China e na Coréia como sistema administrativo e educacional para a reprodução e difusão do conhecimento que serviriam de suporte para o culto ao Paraíso e aos ancestrais ${ }^{30}$.

Afirmando que, ao contrário do que outros estudiosos repetem, o confucionismo ocupou uma posição muito desprivilegiada na primeira metade do período Edo, Kurozumi lembra a classe social dos jusha, intelectuais confucionistas, para concluir que eram "marginais e parasíticos à economia e ao sistema de valor predominante" e de seus adeptos, que eram "uma vanguarda cultural sem raízes da qual a sociedade havia se descartado" Quando suas atividades começaram a ser valorizadas, abriram salas de palestras e escolas nas cidades ou áreas suburbanas, sem aceitação institucional "até a segunda metade do século XVIII, quando as coisas começaram a mudar devido a um aumento súbito de escolas rurais e academias privadas"

\section{Kogaku, ou Estudos Clássicos}

A escola heterodoxa confucionista (Kogaku, "Estudos Clássicos") foi representada pelos estudiosos Yamaga Sokô (1622-1685), rônin que contribuiu para a teoria do bushidô; Itô Jinsai (1627-1705), oriundo de família de comerciantes, que enfatizava as virtudes dos primeiros trabalhos confucionistas, especialmente os Analetos e Mencius;

28. Idem, p. 80.

29. Kurozumi Makoto, "The Nature of Early Tokugawa Confucianism", in The Journal of Japanese Studies, pp. 337-375.

30. Idem, p. 340.

31. Idem, p. 341. 
e Ogyû Sorai (1666-1728), filho de médico a serviço do xôgum, que concentrou seus estudos nos antigos, principlamente nos Cinco Clássicos, rejeitou a doutrina de Chu Hsi centralizada no conhecimento do Paraíso e enfatizou o conhecimento do homem. Objetivavam um estudo mais profundo dos primeiros escritos confucionistas, ao invés de se contentarem com suas versões mais recentes, tentando retroceder até os filósofos da dinastia Sung.

Ogyû Sorai foi importante e influente: sem sua obra, nem a visão da filosofia como uma história das idéias de Tominaga Nakamoto nem os estudos filológicos profundos de Motoori Norinaga ou a vertente Mito, que argumentava que o confucionismo era básica e originalmente uma filosofia política, teriam sido possíveis. Caracterizou-se, em termos lingüísticos, por se recusar a seguir a prática de estudiosos japoneses de colocar o idioma chinês na ordem fraseológica japonesa, suas traduções tendo sido livres e em linguagem contemporânea, num estilo formal japonês elegante e cuidadoso. Em termos históricos, aplicou os métodos filológicos aos sistemas da era clássica chinesa: o Caminho dos Primeiros Reis ${ }^{32}$ chinês foi estabelecido como um absoluto com o qual todos os confucionismos subseqüentes se relacionariam e através do qual seriam compreendidos, respeitando-se os fatos concretos e as técnicas especiais de governo de cada época. Tentou distinguir entre uma ética pessoal e política, pretendendo estabelecer a natureza verdadeira da última por um método histórico objetivo. Assim, o Caminho dos Primeiros Reis seria um método ideal de governar mas não um Caminho da Natureza e do Universo. Natureza e Universo estariam além da compreensão humana. O Caminho dos Primeiros Reis teria sido fato histórico, governo real e material ${ }^{33}$.

Sokô tentou uma crítica ao confucionismo mas foi extremamente vago. Em sua obra Chûchô Jijitsu (Fatos da Nação Central, 1669) o Japão seria o centro do mundo; seus imperadores, superiores aos da China; sua beleza natural ímpar e sinais de sua superioridade seriam a linha ininterrupta da família imperial, a corte aristocrática e sua cultura, a literatura, as artes e as artesanias.

É interessante notar que, sob um disfarce de estudos dos clássicos, formou-se uma academia que acabou por se tornar porta-voz da classe dos comerciantes, legitimando suas funções e enaltecendo suas qualidades. Muitas academias de comerciantes foram fundadas na época, seja de poesia, botânica, história, ciências, economia, entre elas a Kaitokudô, uma academia para "refletir profundamente sobre o significado da virtude", que iniciou suas atividades em 1726 próximo aos estabelecimentos ricos de Ôsaka, recebendo donativos de seus freqüentadores. Tinha uma organização difusa, baseada na lei pública, já que era mantida por um grupo eleito de comerciantes, não tendo tido uma rede expansiva de academias-satélite. Seu modus operandi incluía troca de pagamento pelo conhecimento lá adquirido (quem podia pagava em moeda ou material escolar ou trabalho); todos os freqüentadores eram tratados igualmente, sem distinção de classe; os comerciantes poderiam sair das palestras sem autorização dos instrutores; havia um clima de seriedade e austeridade moral (sem festas e bebidas); proporcionavamse cursos básicos aos jovens, palestras sobre textos chineses e estudos avançados sobre

32. Refere-se ao primeiro confucionismo, dos séculos V a III a.C., de forte apelo comunitário e familiar.

33. Katô Shûichi, História da Literatura Japonesa, vol. 2, pp. 60-69. 
a necessidade prática versus a visão intelectual; selecionavam-se os instrutores de acordo com o talento e não com a sucessão hereditária.

Em um estudo extenso sobre a academia, que foi mantida pelas casas comerciais de Ôsaka por 150 anos, e seu desenvolvimento, Tetsuo Najita ${ }^{34}$ conclui que os comerciantes "desenvolveram uma ideologia que justificou seus atos economicamente no campo público, tornando suas análises e acertos em economia, atos políticos. A história intelectual do Kaitokudô revela claramente esta linha dinâmica de desenvolvimento" 35 . Assim, a virtude dos comerciantes, uma epistemologia que vai ser delineada através da adoção de idéias de várias fontes, incluiu o budismo, o xintoísmo, a filosofia de Chu-Hsi assim como também algumas fontes holandesas.

No início do século XVII, os comerciantes iniciam sua autodefinição enquanto categoria; não se rebelaram, no entanto, em nenhum momento, contra a classificação do xogunato, mas sentiram a pressão de rearticularem a posição que passaram a ocupar dentro da nova ordem. Em relação às guerras militares, eram desengajados, "desatrelados", conformando-se numa distância espacial e não necessariamente hierárquica. Suas cidades-mercado eram locais de separação (muenjo ou engiri basho), onde relações sociais e políticas podiam ser "amenizadas", "cortadas", por se tratarem de locais públicos (kugai, escrito com os ideogramas público-mundo), "local de sofrimento" (kugai, escrito com os ideogramas sofrimento-mundo), pois dividido e experenciado por todos das diferentes classes, numa aproximação budista. Seus santuários e locais de repouso, diversão e criação $(r a k u)$ tornaram-se as áreas do teatro kabuki e dos bairros do prazer. Podemos, então, relacionar esses três elementos, muen, kugai e raku, como essenciais na definição dos chônin enquanto classe, num primeiro momento.

Os comerciantes, já habitando a cidade baixa, a "cidade das águas", se tornam, eles próprios, seus elementos: seu mundo é o mundo do "fluxo", privados de estipêndio e terras aráveis. Assim, as "virtudes 'frugalidade', 'cálculo', 'perspicácia', 'diligência', 'honestidade', não são simples injunções morais derivadas de princípios abstratos mas referências a estratégias práticas às quais os comerciantes enfrentarão de geração a geração para adquirir uma continuidade diretamente paralela à que já era garantida à aristocracia por nascimento"36 (grifo meu). Os comerciantes estão, portanto, em desvantagem com relação às outras classes. Nippon Eitaigura, obra de Ihara Saikaku (1642-1693) e Chônin Kôken Roku, de Itô Jinsai (1627-1705), tratam dos aspectos, positivos o primeiro e negativos o segundo, para os comerciantes alcançarem o sucesso, ambos reconhecendo a incerteza e impredicabilidade que é um fato central em suas vidas.

34. "Kaitokudô: Visions of Virtue", Tokugawa Japan. Yamashita qualifica a análise cuidadosa e sistemática do discurso da Academia Kaitokudô realizada por Najita como modelo de como se contextualizar idéias, fazendo parte de uma nova abordagem histórica, a saber, a das periferias: a academia da classe desprezada dos comerciantes estaria na periferia das incontáveis academias de Estudos Confucionistas, Jugaku.

35. Op. cit., p. 9.

36. Op. cit., p. 21. 
A água, e seu fluxo, que comparece já na nomeação do tipo de narrativas citadinas (ukiyo, "mundo flutuante") será mais uma vez a metáfora recorrente do momento cultural japonês em Edo, englobando os comerciantes que, ao sabor das ondas, sobem ou descem de padrão econômico e também samurais que, perdendo sua função de guerrear, começam a servir os ricos comerciantes, naquilo que eles mais almejam, a saber, na aquisição de conhecimentos e na apreensão e prática de novos Caminhos. A metáfora da água comparece também como presença física que separa o mundo dos prazeres e dos sentimentos humanos do mundo do cotidiano, dos deveres e obrigações.

Uma outra questão importante na teorização dos comerciantes vai ser o conceito budista da capacidade humana universal da compaixão, jihi, que se entendia ser inexistente nos comerciantes por causa de sua atividade profissional que visaria somente o lucro. Jihi foi enfatizada pelos comerciantes pelo viés do byôdo, da igualdade nas leis das mudanças e da morte (Shisei wa kotogotoku byôdô nari - "na vida e na morte todos são iguais"; Ichi byôdô nishite ni nashi - "existe somente a igualdade"), ponto de vista que se encontra no confucionismo, no budismo e no xintoísmo, no sentido de que a potencialidade para a ação moral é garantida, o espírito divino ou kokoro existe em todos e em tudo sem distinção. Portanto, distinções de status, poder e riqueza não têm significado e, assim, "os comerciantes se viam sem classe sob o ponto de vista espiritual, enxergando na função particular de sua classe uma centricidade moral universal que deveria sobreviver de geração a geração" 37

Indo mais à frente, Miyake Kanran (1674-1718), intelectual jusha, também proprietário de uma farmácia de ervas (o que o tornaria um comerciante), articulando suas idéias com as de Itô Jinsai e outros pensadores plebeus, destacou a importância do lucro para os comerciantes: o lucro não seria mais que a extensão da razão humana, da epistemologia da "virtude" ( $g i$ ), quando a virtude age no mundo objetivo; o lucro emerge sem esforço e espontaneamente, sem distúrbios passionais; o lucro não precisaria ser mera paixão mas uma extensão moral da virtude. Como bem analisa Najita,

Dizendo à audiência que eles, os comerciantes, possuíam a virtude de controlar a academia pública como seu espaço "comunal", como "colegas", que eles poderiam almejar os conhecimentos ensinados pelos sábios antigos, Miyake (apesar de todo seu ecletismo), através de seu ponto de vista, transformou a filosofia moral do neoconfucionismo que o xogunato utilizara para conformar distinções sociais hierárquicas como extensões da razão natural ${ }^{38}$.

Nas mudanças ocorridas nas eras Genroku (1688-1703) ${ }^{39} \mathrm{e}$ Kyôhô $(1716-1736)^{40}$, o retorno à ética do "desligamento e desengajamento" do mundo era visto como

37. Op. cit., p. 24.

38. Najita Tetsuo, Kaitokudô, p. 94.

39. Foi durante a era Genroku que o poder econômico dos chônin, "habitantes das cidades", classe composta principalmente de comerciantes, se estabeleceu e atingiu um auge súbito. Embora datada historicamente entre 1688 a 1703 , a característica do período o estende até 1725 aproximadamente. Note-se que as narrativas ukiyo-zôshi atingiram seu auge durante o período e os procedimentos xilográficos multicoloridos das assim chamadas "pinturas-brocado" se aperfeiçoaram.

40. Era problemática, no período Kyôhô deram-se muitos acontecimentos marcantes, entre os quais uma grande epidemia de fome (1732) de proporções gigantescas que se abateu sobre Kyûshû, Shikoku e até 
impossíveis. Duas novas orientações filosóficas então surgiram e foram centrais para a academia Kaitokudô. Primeiramente, a teoria historicista de Itô Jinsai, que rejeitou o neoconfucionismo, voltando aos textos históricos da China antiga para reintroduzir em seu tempo um valor universal para os citadinos. Depois, os trabalhos de Kaibara Ekken e Nishikawa Joken, este último comerciante autônomo de Nagasaki, extraíram do neoconfucionismo a idéia de uma razão absoluta na natureza (tenri) que estaria em todos os homens, rejeitando portanto uma ênfase hierárquica. Kaibara dirigiu sua teoria para construir uma ciência agronômica para os camponeses; Nishikawa dirigiu-se aos comerciantes e também aos camponeses.

Vejamos algumas das idéias de Nishikawa em sua obra Saco de Comerciantes: refletindo sobre a riqueza, diz que "o dinheiro tem uma vitalidade natural (shizen no ikiyoi $)^{41}$, é público, social, móvel e não pertence a nenhuma classe ou casa ou corte em especial; a riqueza não fica estática, assim que pára já se reverteu e começou a se dispersar, de acordo com o princípio natural"; assim também a pobreza é relativa e não permanente; a integridade para os comerciantes repousa na inteligência econômica, não na habilidade manual ou nas artes marciais; os comerciantes podem agir em modos éticos precisamente porque seu caráter moral não é diferente do de qualquer outro grupo de seres humanos; assim como as flores crescem em todos os campos, os camponeses são capazes de fazer o trabalho dos samurais se propriamente educados para fazê-lo e, similarmente, os samurais dos camponeses, e também os comerciantes ${ }^{42}$; o dualismo no pensamento neoconfucionista que separava "princípio" e "matéria" é enganador, a natureza é monista, nela todos os fenômenos são partes integrantes de uma ordem material unificada ${ }^{43}$; os governantes devem identificar-se com o princípio altruísta dos serviços devidos aos governados, os camponeses devem fazer a colheita em seu tempo certo, os comerciantes devem calcular seus lucros precisos; as classes podem existir para a manutenção da ordem, mas estas não devem refletir proposições últimas sobre o conhecimento e a vida; o comerciante é ético, como qualquer outro, e deve usufruir seu mundo de trabalho, não deve nutrir ilusões sobre salvação e reencarnação num status social melhor e sim usufruir a vida como um mero comerciante (tada kono chônin-koso tanoshikere $)^{44}$. Temos, assim, em Nishikawa, um autor que faz a celebração dos comerciantes.

Itô Jinsai e seu resgate dos Estudos Clássicos - estudou os clássicos na fonte -, particularmente sua apreciação de Mencius foi fundamental na formulação de idéias nas quais os comerciantes e os comuns pudessem reconhecer a virtude de suas vidas $e$ de seus trabalhos diários, pois enfatizou uma proposta moral horizontal dos valores humanos universais, e também o processo de "engajamento" foi preferido ao invés da "separação" (muen) da realidade social, que deveria ser aceita como ela é, um espaço moral.

o continente, o aparecimento de cinco variedades de moedas de ouro e prata e a grande reforma Kyôhô

Kaikaku com exortações à frugalidade.

41. Chônin Bukuro, pp. 49-50, citado em Kaitokudô.

42. Idem, p. 52.

43. Idem, p. 53.

44. Idem, p. 56. 
A metamorfose no pensamento dentro da academia Kaitokudô ilustra o ponto geral de que o pensamento Tokugawa continha na economia política do keisei saimin ("organizando o mundo social" e "salvando o povo", conotando a aquisição do conhecimento apropriado para controlar eventos externos aos níveis pessoal e público), ou seja, uma capacidade dinâmica de cruzar linhas nas classes e migrar da aristocracia reinante para assumir um significado ideológico entre os comerciantes de Ôsaka. Que o termo keisei saimin, que poderia ser traduzido por "economismo político", tenha derivado contemporaneamente para keizai, "economia", atesta sua importância.

Para concluir com Najita: "o movimento de idéias pelas estradas cheias da paisagem Tokugawa, como a Tôkaidô, não foi um processo vago e abstrato mas, assim como a transferência de objetos comerciais, estava presa a específicos cargos atravessando rotas concretas e convergindo em locais pivôs tais como a Kaitokudô" 45 .

Percebemos, então, que não somente pelo grande número de novas escolas nas grandes cidades e também nas províncias, independentes, atreladas a templos (teragoya), ou patrocinados pelos comerciantes (shijuku), a difusão do conhecimento que se deu no período Edo não foi simples mímese da aristocracia reinante, mas um amálgama também de tradições e novos enfoques.

\section{Kokugaku ou Estudos Vernaculares ${ }^{46}$}

Kokugaku-ha continuou a ênfase humanista. A obra Grande História do Japão de Tokugawa Mitsukuni seguiu o pensamento de Kitabatake Chikafusa, do século XIV, atribuindo a grandeza do Japão à sua linhagem de imperadores em linha direta de sucessão de descendência divina. Dois monges xintoístas, Kada Azumamaro (1668-1736) e Kamo Mabuchi (1697-1769), estudaram a poesia japonesa clássica e Motoori Norinaga (16971801), médico filho de comerciante, devotou mais de trinta anos para escrever Kojikiden (Comentários sobre Kojiki ${ }^{47}$, a primeira obra histórico-mitológica do Japão), tentando traduzir o pensamento da antigüidade japonesa de modo acadêmico. Rejeitavam o racionalismo secular do confucionismo e buscavam o espírito japonês nos mitos antigos, na poesia clássica da coletânea imperial do século VIII, Man'yôsh $\hat{u}^{48}$, nas narrativas do

45. Op. cit., p. 286.

46. Muitos autores traduzem Kokugaku como Estudos Nacionalistas, pois o ideograma koku refere-se a país, modernamente. No entanto, kuni (leitura japonesa para $k o k u$ ) nomeia não somente um país, como também uma região, tendo sido uma antiga divisão geopolítica. Traduzimos o termo, no entanto, como Estudos Vernaculares, baseados no tipo de estudos perpretados por seus membros e também pelo fato de que o termo nacionalismo envolve outras questōes.

47. Kojiki, Relatos de Fatos Antigos, compilada no período Yamato, tendo sido finalizada no ano 712, é uma obra dividida em três partes: A Idade dos Deuses, narração da criação do mundo e das sete geraç̃ôes de deuses até que Amaterasu gera Nintoku, o primeiro imperador do Japão; A Idade dos Homens, onde os imperadores são cronologicamente enumerados juntamente com seus feitos e A Idade da Terra, onde constam as divisões dos territórios entre os senhores nobres. A obra legitima a supremacia imperial através de sua origem divina.

48. Man'yôshû, Coletânea das Dez Mil Folhas, antologia poética compilada a mando imperial no século VIII, composta de poemas de aristocratas e populares anônimos, estabeleceu para épocas posteriores os 
século XI, do tipo Genji Monogatari ${ }^{49}$. A ênfase nas virtudes dos japoneses primitivos e da linhagem imperial os conduziu a doutrinas subversivas ao sistema Tokugawa. Não só no campo dos estudos intelectuais, mas também na religião, essa tendência de volta ao $k_{0 k o r o}{ }^{50}$ se manifesta também no aparecimento de novas vertentes populares de colorido xintoísta, tais como a tenri-kyô (Ensinamentos da Verdade do Paraíso). OKojiki seria a obra que melhor transmitiria a era antiga do Japão onde "coração, acontecimentos e palavras são equivalentes", através de um método filológico comparativo de todos os usos de cada palavra. Motoori tentou extrair a essência japonesa: "a menos que se componha waka é impossível conhecer o belo coração dos antigos ou a essência da elegância"s!.

\section{H. D. Harootunian ${ }^{52}$ salienta que}

[...] os intelectuais dos Estudos Vernaculares adotaram uma estratégia que os comprometia a uma caracterização de redução metonímica pela exploração de um artifício arcaizante que prometia representar a realidade mais plenamente pela recuperação do significado corpóreo e tangível que a linguagem existente não podia captar ou representar acuradamente. Isto explicaria sua concentração nos estudos poéticos, [...], seu interesse intenso pela linguagem [...], sua ênfase deliberada nos vocábulos e na sintaxe arcaicos, intocados pelo "sentimento chinês" (kara-gokoro); contaria também para a preferência de muitos em escrever no que era de fato dialeto local, para a tendência à especulação cosmológica levando a uma cosmogonia sistemática e, finalmente, para a natureza restauracionista de sua estratégia.

De fato, o retorno de Motoori Norinaga ao estudo de uma obra como o Kojiki bem atesta o interesse restauracionista e arcaizante acrescentando um matiz nostálgico mas ainda assim um fruto de seu tempo: "na idade dos deuses os homens deliberaram de uma perspectiva humana; nós almejamos entender as coisas humanas do ponto de vista da idade dos deuses" (hito wa hito no ue motte kamiyo hakaro wo, ware wa kamiyo wo motte hito no koto wo shireri), ou seja, através do esclarecimento dos "traços" da antigüidade descobrir-se-iam as verdadeiras dimensões do fenômeno humano na

maiores cânones poéticos japoneses, tais como temas (amor, separação, estações sazonais e seus respectivos pássaros, flores, locais famosos, cores) e formas (chôka, tanka, sedôka).

49. Genji Monogatari, obra monumental escrita pela dama da corte Murasaki Shikibu entre os anos de 1001 a 1020, foi o primeiro grande livro em prosa da literatura japonesa, em silabário fonético, invenção feminina em contraposição ao domínio dos ideogramas chineses entre os nobres japoneses. Tornou-se o cânone literário do período Heian e marcou todo o imaginário artístico posterior com suas longas descrições sobre o ideal de vida cortês.

50. Kokoro, já teorizado nos prefácios Kanajo e Manajo de Ki no Tsurayuki e Ki no Yakamochi, da coletânea imperial Kokin Wakashû (Coletânea de Poemas Japoneses de Hoje e de Ontem), ou Kokinshû, do século X, pode ser entendido como, do ponto de vista poético: mente, coração, intenção, sentimento, sinceridade, conteúdo. Opõe-se a kotoba: palavra, signo, tradição, forma, recurso poético. Os dois conceitos se manterão inalterados na poética japonesa, tendo sido retomados ad infinitum. Além dessa acepção, kokoro do ponto de vista cotidiano denota a alma, a intenção verdadeira, a sensibilidade.

51. Citado em Katô Shûichi, História da Literatura Japonesa, vol. 2, pp. 180-188.

52. "The Consciousness of Archaic Form in the New Realism of Kokugaku" In Najita Tetsuo \& Irwin Scheiner (eds.), Japanese Thought in the Tokugawa Period 1600-1868 - Methods and Metaphors, Chicago \& Londres, The University of Chicago Press, 1978, pp. 80-81. 
representação mítica ${ }^{53} \mathrm{O}$ neoconfucionismo, em sua tentativa de entender a modalidades e a existência em termos das atividades racionais dos seres humanos, seria representativo do kara-gokoro, em oposição ao wa-gokoro ou yamato-gokoro, o "sentimento japonês" Como não poderia deixar de ocorrer, em sua procura pela "essência japonesa", descobre o mono no aware ${ }^{54}$, onde empatia e intuição substituem o racionalismo confucionista, a particularidade e unicidade substituem o princípio, a categoria e a tipificação, o tangível substitui o intangível. Todas as coisas são expressões dos poderes dos kami, divindades, que são responsáveis pelas coisas, pela correspondência do indivíduo e do tipo e pela harmonia na ampla totalidade cósmica por todos os tempos vindouros. Nessa nova ênfase em elementos antagônicos à filosofia confucionista, os intelectuais vernaculares descobrem um novo modo de consciência histórica. Vemos em Motoori Norinaga uma retomada do xintoísmo que, no entanto, não resolveu a proposta de explicar aos seus contemporâneos a relação das particularidades e sua importância.

A história então revalorizada por Motoori abriu caminho para a teoria de história cosmológica de Hirata Atsutane (1776-1873), que alargou os limites dos Estudos Vernaculares, tendo criado condições de um modo de representação histórica no qual incluísse as massas de não-samurais, tendo-se afastado dos estudos poéticos e se dedicado a interesses práticos e à construção de uma cosmologia coerente. Influenciado talvez pelos levantes de camponeses de seu tempo, tentou explicar os conflitos e rebeliões como um processo histórico, tendo-se recusado a aceitar a autoridade das histórias antigas e elegendo apenas textos e partes destes que fossem apropriados às suas necessidades para formar elos entre o presente e o passado.

A principal contribuição de Hirata Atsutane teria sido sua revisão do discurso dos Estudos Vernaculares de modo a fornecer uma base firme para contestar a "cultura e ideologia oficiais". Harootunian estudou a difusão que tais ensinamentos tiveram nas províncias nos anos de $1800^{55}$, concentrando-se em grupos que chamou de "alto campesinato" ou "notáveis locais", na tentativa de resolver desordens e aumentar a produtividade agrícola. E assim fazendo, interpretou os Estudos Vernaculares como um meio de compreender o que estava acontecendo no meio rural, reduzindo o impacto dessas mudanças interpretando-as em termos da narrativa cosmológica de Hirata e transformando "história" em "cultura". Ao fim, constestaram a ideologia oficial, premidos pelas mudanças no modo de produção e na resultante inquietação social ${ }^{56}$.

Assim, nos estudos mais recentes tem sido aceita a afirmação de que a ideologia Tokugawa assumiu muitas formas diferentes, tendo-se manifestado não apenas em

53. Harootunian, "The Conciousness of Archaic Forma in the New Realism of Kokugaku", Japanese Thought, in the Tokugawa Period-Methods \& Metaphors, p. 82.

54. Mono no Aware, "a tristeza-beleza das coisas", conceito filosófico do período Heian, traduz o conceito de uma intensa empatia com o universo exterior. Aware transmitiria nuanças da percepção (nunca excluindo as sutilezas do olfato) e do conhecimento de modo introspectivo, melancólico, intenso. Também por asssociação, ideal estético almejado nas Narrativas de Genji e na vida palaciana.

55. Harootunian, Things Seen dan Unseen: Discourse and Ideology in Tokugawa Nativism. Chicago, University of Chicago Press, 1988.

56. Yamashita, "Reading the New Tokugawa Intellectual Histories", in The Journal of Japanese Studies, vol. 22, n. 1, Seattle, University of Washington, 1996, p. 31. 
discurso político formal mas também através de rituais xintoístas de autodeificação e mitificação. De acordo com Ooms ${ }^{57}$, a contribuição confucionista ao novo discurso político foi na verdade bem modesta: Fujiwara Seika acrescentou uma dimensão espiritual importante; Yamasaki Ansai, uma geração depois, sintetizou xintoísmo e neoconfucionismo e outros simplesmente "embelezaram" o novo discurso.

Ignorado em seu tempo, tendo sido mencionado apenas por Motoori Norinaga e Hirata Atsutane, Tominaga Nakamoto (1715-46) foi redescoberto apenas no período Meiji. Filho de comerciantes de Ôsaka, Tominaga desafiou o pensamento tradicional do período numa crítica direta ao confucionismo, budismo e xintoísmo, através de um método experimental científico onde avaliou as doutrinas pela lógica interna de suas próprias idéias, por mudanças na linguagem e pela influência cultural provocada, tendo sido expulso da academia Kaitokudô. Seus conhecimentos profundos dos clássicos búdicos influenciaram posteriormente Motoori Norinaga. Tominaga fez do conceito de universalidade um método intelectual, não considerando o xintoísmo autóctone do Japão, pois os princípios básicos da fé podiam e transcendiam considerações de nacionalidade, não se opondo assim aos pensamentos de origem estrangeira (chinesa). Para ele não havia Caminho, pois no confucionismo este tomaria a forma de retórica e oratória; no budismo, a de mágica e feitiçaria; no xintoísmo, a de mistérios e artes divinas que propiciariam ou engodo ou roubo.

Se entendemos o neoconfucionismo como um movimento de importação de idéias chinesas, desta vez buscadas pelos samurais no poder, os Estudos Vernaculares exerceram, então, um papel profundamente anticonfucionista, pois tentaram reestabelecer contemporaneamente o espírito japonês, através do estudo de seus clássicos.

\section{Shingaku ou Estudos do Coração}

É também interessante notar o fato de que começaram a surgir pensadores de outras classes sociais: Ishida Baigan (1685-1744), de origem camponesa, ensinava que comerciantes honestos e diligentes desempenhavam uma função nacional comparável à dos samurais, proporcionando-lhes uma legitimidade moral, provendo-lhes uma razão para justificar seu lucro fabuloso. As palestras de Ishida Baigan iniciaram o Shingaku (Estudos do Coração) em Kyôto, em 1729, uns três anos após a fundação do Kaitokudô. Baigan utilizava três métodos de ensinamento: as palestras abertas a qualquer interessado sem exceção e sem taxas, encontros também abertos para sessões de perguntas e respostas e a prática da meditação. Salientava antes de mais nada o que chamava de gakumon (estudo), através da meditação que levaria à iluminação, um processo vertical para se conhecer o kokoro, a natureza (numa apropriação de idéias budistas, xintoístas e confucionistas), e da pregação, um processo horizontal da prática ética que se lhe segue. De suas duas obras publicadas, Toimondô (Diálogo da Cidade e da Província) e Seikaron (Teses sobre a Administração da Casa), entende-se que possuir fé, seja na lei do Buda para atingir a salvação ou nas virtudes da deusa Amaterasu ou na essência espiritual

57. Op. cit. 
universal do pensamento neoconfucionista é uma manifestação do Caminho dos céus (tendô), e não deve ser diferenciada dos sofismas doutrinais. Ishida Baigan então, ao afirmar que todos os indivíduos independentemente do status possuem essência universal, que é sábia e boa, retira o estigma do desprezo em relação à classe dos comerciantes classificados como parasitas dentro do sistema produtivo; a ética do comércio seria, então, a acurácia, não sendo inferior à ética da aristocracia guerreira, o lucro não diferindo do estipêndio dos samurais pois ambos seriam formas de dádivas dos céus.

É importante ressaltar, no entanto, que a valorização do trabalho dos comerciantes não significou rejeição ou criticismo ao sistema do xogunato, mas antes, numa afirmação firme de seus valores dominantes: os camponeses produziam, os samurais administravam, os artesãos construíam, os comerciantes distribuíam, cada classe ocupando seu lugar legítimo. Baigan se opunha, no entanto, a um lucro injusto e exortava à honestidade (shôjiki) que levaria à prosperidade, se não imediatamente, num futuro próximo, condenando lucros rápidos e baseados em truques espertos ou no não pagamento de dívidas ou no desrespeito à propriedade.

Embora houvesse dedicado a vida inteira e praticado intensamente sua nova doutrina, coube, no entanto, a Teshima Toan (1718-1786), seu discípulo, o papel de grande líder e hábil organizador na estabilidade institucional. Oriundo de uma antiga família rica de comerciantes de Kyôto, Toan se tornou discípulo de Baigan aos dezoito anos, tendo atingido a iluminação em 1738 , fato reconhecido pelo mestre. A estruturação organizada por ele compreendia uma espécie de filiais, kôsha, que eram construções simples de 20 a 30 tatamis, onde o espaço maior era dedicado a pregações; compunhamse de um altar a Amaterasu e um retrato do mestre, que ali também moraria (shashu); dois a sete auxiliares (tokô), estudantes que meditavam e recebiam orientação (shonyu) e pregadores iluminados (kôshi), que deveriam ter "certificado de iluminação" 58 . Ao tempo da morte de Toan, havia 22 kôsha em catorze províncias e o movimento continuou a crescer: em 1789 eram 34 kôsha; em 1795, 56; em 1803, 80 e em 1830, 134 estabelecimentos espalhados em 34 províncias.

A publicação de livros contendo os ensinamentos básicos esteve também a cargo dessas escolas, muitas vezes contendo ilustrações adaptadas de $\hat{o t s u-} e^{59}$ Jennifer Robertson interpreta a apropriação desse tipo de imagens, que poderiam ser facilmente reproduzidas até por estêncil, no sentido de que seria uma forma artística de produção de massa, onde a consciência estética não seria determinante; assim, também, "o anonimato e a qualidade geral, sem personalidade, das imagens (que) talvez tenham tocado os líderes do movimento como sinônimos dos conceitos-chave do Shingaku de não-egoísmo e não-racionalização. $\mathrm{O}$ trabalho em equipe requerido na produção das

58. Densho, os certificados de iluminação, começaram a ser outorgados em 1780; consta que em 1880 por volta de 36.000 pessoas o detinham. Num primeiro momento eram emitidos somente pela casa matriz, mas posteriormente outros kôsha começaram a emiti-los.

59. Ôtsu-e, "imagens de Otsu", a última estação-pousada de Tôkaidô, antes de Kyôto. Nesse local produziram-se imagens xilográficas coloridas a mão caracterizadas por serem imagens simples, cujos temas provinham de fontes ecléticas, servindo como souvenirs, retratando eventos e personagens históricos, temas religiosos, folcóricos e também alguns ukiyo-e. 
imagens também lembrava a natureza coletiva dos exercícios executados nos pequenos grupos de estudos" ${ }^{\prime \prime}$, numa análise curiosa de equivalência entre a prática da construção de imagens visuais e a prática da construção de pensamentos. Como não deixar de associá-la também à divisão minuciosa de tarefas na produção das estampas xilográficas do mundo-flutuante, das quais as gravuras Ôtsu-e são precursoras? Mais que não-egoísmo ou não-racionalização, parece-me que a produção coletiva dessas estampas segue a tendência da divisão de trabalho que permeou todo o período Edo; maior produção, maior especialização.

Se Toan estabeleceu a estrutura do Shingaku, coube a seu discípulo Nakazawa Dôni (1725-1803), enviado a Edo em 1780, onde fundou Sanzensha no ano seguinte, o papel de maior e mais influente pregador, com uma apropriação maior do budismo (era de uma família de tecelães adeptos do budismo nichiren e depois do zen), e uma associação com o xogunato, utilizando pregações para expor editos governamentais nos quais se exortava à lealdade, piedade filial, diligência, frugalidade no consumo, paz pública e à estrita obediência aos oficiais, em oposição à dissipação nos entretenimentos hedonistas e jogos. Essa associação cada vez mais íntima com o xogunato foi fatal com a Restauração Meiji em 1868: o Shingaku valorizava a unificação dos três sistemas morais básicos - xintoísmo, budismo e confucionismo (sankyô itchi) -, mas a nova doutrina vigente vai ter um predomínio quase que exclusivo do xintoísmo em sua revalorização do imperador. Então, o prestígio do sistema educacional dos kôsha foi substituído por um sistema escolar nacional no novo governo; sua associação ao xogunato, suas incertezas quanto à base doutrinal a ser seguida nos novos tempos e a fragmentação interna que já vinha ocorrendo em sua estrutura também precipitaram esse processo.

No entanto, sua importância no pensamento japonês deixou um lastro notável, pois seu conteúdo ético continuou a ser propagado nos novos livros didáticos do novo sistema de ensino público, suas idéias foram reapropriadas pelo novo movimento xintoísta e, embora as técnicas da meditação fossem descartadas, a idéia de se unir o espírito humano com o Paraíso, céu e terra, continuou a existir. Ou, como conclui Robert Bellah:

Como religião pregava a iluminação e a devoção altruísta que era tanto um meio para ela quanto uma consequiência dela. Politicamente reforçou a racionalização e a extensão do poder pela ênfase à grande importância da lealdade e do altruísmo dos servos. Sua ênfase no imperador foi importante, apesar de seus laços com o xogunato, na preparação da opinião popular para a Restauração. Embora um movimento da classe dos comerciantes não almejou nenhum poder político para si mas aceitou os samurais como líderes políticos [...] Economicamente reforçou a diligência e a economia, valorizou a produtividade e minimizou o consumo. Além disso defendeu padrões universais de honestidade e respeito [...], contribuiu para o crescimento de uma atitude contínua, prática e disciplinada em relação ao trabalho entre as classes citadinas, importante tanto para os empreendedores quanto para os trabalhadores numa economia que se iniciava no processo da industrialização ${ }^{61}$

60. "Rooting the Pine - Shingaku Methods of Organization", in Monumenta Nipponica, vol. 34, n. 3, 1979, pp. $328-30$.

61. Tokugawa Religion - The Cultural Roots of Modern Japan, pp. 175-176. 
Podemos notar que as conclusões de Bellah acerca dos Estudos do Coração interpretam o movimento como religião, tentando relacioná-lo fortemente com a Restauração Meiji e ao mesmo tempo com a modernização industrial do século $\mathrm{XX}$. Com efeito, utilizando o sistema ie-moto de organização, apropriando-se de técnicas budistas de meditação e de um sistema de valores do neoconfucionismo, os Estudos do Coração em muito contribuíram para o sincrético mundo do pensamento japonês.

Em 1930, Toan recebeu postumamente o mais alto título da corte já atingido por um cidadão comum, por ocasião do $200^{\circ}$ aniversário do movimento. Mas não devemos minimizar o fato de que, para os samurais do período Edo, o movimento foi extremamente conveniente, tendo extrapolado sua função como veículo para a busca de identidade dos citadinos e servido para todas as classes sociais do Japão nos fins do século XVIII e do XIX.

\section{Conclusão}

São tidas irresolutamente como representantes de valores neoconfucionistas da sociedade Tokugawa muitos temas literários, entre os quais o dramático embate entre giri (obrigação) e ninjô (sentimento humano) que tanto percebemos nas peças de Chikamatsu Monzaemon, mas a nosso ver este embate ocorre justamente como uma metáfora entre o espírito kara-gokoro (estrangeiro, lógico, duro, direto, social, masculino, exterior, do outro) e o espírito wa-gokoro (suave, redondo, interior, lírico, elíptico, evasivo, sensitivo, do íntimo, feminino) protagonizado pela nova classe social do período Edo, os citadinos (chônin). No pensamento neoconfucionista não haveria espaço para tais conflitos - as piedades devem ser seguidas à risca -; os conflitos surgiram justamente devido à dificuldade da aceitação de uma ordem - o sentimento humano irreprimível - por outra - a ética racional e firmemente estabelecida -, e encontraram expressão artística particularmente no mundo dos comerciantes, que, de certo modo, assim ofereceram sua resistência à tentativa de adoções de medidas neoconfucionistas chinesas por parte do xogunato. Podemos ler amiúde nas narrativas curtas de Saikaku como os pequenos comerciantes se furtavam ao obedecimento das regulamentações suntuárias do xogunato, vestindo ricos brocados e tecidos coloridos a mão por debaixo de rudes algodões.

A nosso ver, se algo se caracterizou como porta-voz de um pensamento neoconfucionista, este foi o bushidô, centralizado nos deveres para com os senhores, sem conflitos com os sentimentos humanos, ou melhor, os sentimentos humanos se realizam na plenitude da lealdade devida a seus superiores, numa metodologia de controle do instinto e até de autopreservação irracional em nome de um anular-se de si mesmo em prol de seus senhores e mesmo nesse campo o sentimento extático de servir confere à lealdade um caráter mais dramático do que propriamente racional (é muito citado o "racionalismo confucionista" por estudiosos do assunto).

Notamos também que a tradição ainda mostra sua permanência e um prestígio enorme nos dramas históricos, na composição de haiku, nas pinturas de usos-e-costumes 
(fûzoku-ga), nas artes decorativas e corporais ${ }^{62}$, onde não se percebem preocupações com os problemas imediatos gerados pela tensão entre o sucesso econômico dos comerciantes e a ordem política a cargo dos samurais cada vez mais empobrecidos, tendo antes um caráter temático atemporal, ou melhor, centralizados ainda na era Heian. Se a era Heian foi, como interpreta o estudioso Katô Shûichi, o primeiro momento japonês, quando se atingiu uma maturação e uma síntese toda particular, após séculos de importação cultural da China, no período Edo ter-se-ia dado este segundo momento, agora não de uma cultura aristocrática, mas citadina, que manteve, entretanto, uma série de laços com seus clássicos que não deve ser desprezada - ou melhor, este segundo momento japonês espelha seu primeiro auge através de uma versão dela, não necessariamente um espelho esmaecido, mas, como foi o caso, através de formas novas (o livro xilografado, as estampas xilográficas), temas novos (representações teatrais, divertimentos em vistas internas e externas, as cidades e seus habitantes), novos paradigmas. Até mesmo escritores e artistas que representariam a classe dos comerciantes e citadinos fazem em sua obra não poucas alusões aos clássicos: Saikaku compôs haikai no renga e sua prosódia seguia quase sempre uma certa versificação alusiva a poemas clássicos, Moronobu ilustrou as Narrativas de Genji, Chikamatsu Monzaemon também produziu dramas históricos (rekishi-mono), o século XVIII vê renascer um interesse grande na releitura de suas obras clássicas, como podemos ver na obra de Bakin e Ueda Akinari. E por que não relacioná-lo também ao conceito do belo prevalescente no período Heian, do aware ou mono no aware, onde a relação de beleza/tristeza se passa entre o eu e a natureza, mesclado a tintas já do sentimento de transitoriedade (mujôkan). Assim, na passagem eu-e-natureza (período Heian) para eu-e-sociedade (período Kamakura) o sentimento humano da transitoriedade se faz mais forte para ser, afinal, no período Edo, na relação entre o eu-e-o-outro, se transformar em um sentimento de "mundo flutuante", uma transitoriedade onde os sentimentos humanos se encontram negados, à deriva, tendo gerado o tema shinj $\hat{u}^{63}$. Que Bashô tenha buscado nos longínquos rincões das províncias material poético também o liga ao momento de invenção dos "locais famosos"

Como vimos neste estudo, também no pensamento, não ocorreu uma importação do neoconfucionismo simplesmente, que teria sido dominante em todo o período Edo, mas houve muita discussão e interpenetração de diferentes conteúdos e, principalmente, muitas mudanças. Notamos embates entre o importado neoconfucionismo e o já japonizado xinto-budismo, que resultou num novo amálgama, tendo sido certas idéias deglutidas, outras totalmente descartadas, umas tantas adaptadas, às vezes vagamente discerníveis nos novos produtos culturais criados pela nova categoria social dos homens das cidades em sua ascensão econômica, idéias estas às vezes inequivocadamente

62. Entendo aqui como artes decorativas a cerâmica, a pintura em leques, biombos, portas corrediças, objetos laqueados, objetos vários, o quimono; e como artes corporais a cerimônia de chá, a dança em si ou nas representações teatrais, o arco-e-flecha, as artes marciais.

63. Shinjû, hoje mais conhecido como duplo suicídio amoroso, teve sua origem como "prova de verdadeiros sentimentos". Assim, a cortesã, para mostrar seu amor real a um amante-cliente lhe ofertaria uma mecha de cabelos, um objeto pessoal, eventualmente a falangeta do dedo mínimo e, maior prova de amor irrestrito, acompanhá-lo na morte devido à impossibilidade da concretização de seu amor no mundo cheio de relações sociais - giri. 
ortodoxas em sua origem mas transformadas em seu processo de assimilação. Principalmente vimos um retorno aos clássicos no movimento dos Estudos Vernaculares, e um renascer espiritual dos Estudos do Coração, que desempenharam papéis importantes no período Meiji e ainda hoje os estudos de Motoori Norinaga são decisivos ao nos debruçarmos sobre obras clássicas japonesas, principalmente no Kojiki (Relatos de Fatos Passados), obra inicial da justificação divina do imperador.

\section{Bibliografia}

ABE, Jirô. Tokugawa Jidai no Geijutsu to Shakai (A Sociedade e as Artes do Período Tokugawa). Tôkyô, Kadokawa Shoten, 1950.

ARMSTRONG, Robert Cornell. Light From the East: Studies in Japanese Confucianism (Luzes do Oriente: Estudos sobre Confucionismo Japonês). Toronto, University of Toronto, 1914.

BELLAH, Robert N. Tokugawa Religion - The Cultural Roots of Modern. Japan (Religião Tokugawa - As Raizes Culturais do Japão Moderno). New York, Londres, The Free Press, 1985 ( $1^{\text {a }}$ ed. 1957).

BıTô, Masahide (ed.). "Studies on Bushi (Samurai)". In Acta Asiatica, n. 49. Tôkyô, The Tôhô Gakkai, 1985.

BODART-BAILEY, Beatrice. "The Persecution of Confucianism in Eartly Tokugawa Japan" ("A Perseguição do Confucionismo no Período Inicial do Japão dos Tokugawa"). In Monumenta Nipponica, vol. 48, n. 3, pp. 293-314. Tôkyô, Sophia University, 1993.

BolitHo, Harold. "Concrete Discourse, Manifest Metaphor, and the Tokugawa Intellectual Paradigm" In Monumenta Nipponica, vol. 35, n. 1, pp. 89-98. Tôkyô, Sophia University, 1980.

CARRÉ, Guillaume. "Communautés bourgeoises à l'époque d'Edo" ("Comunidades Urbanas na Era Edo"). In Cipango Cahiers d'études japonaises, n. 4. Paris, Institut national des langues et civilisations orientales, 1995.

CHING, Julia. "Chu Shun-shui, 1600-82: A Chinese Confucian Schola in Tokugawa Japan" ("Chu Shun-shui, 1600-82: Um Intelectual Confucionista Chinês no Japão da Era Tokugawa"). In Monumenta Nipponica, vol. 30, n. 2, pp. 177-192. Tôkyô, Sophia University, 1975.

COALDRAKE, William H. "Edo Arquitecture and Tokugawa Law" ("A Arquitetura de Edo e as Leis Tokugawa"). In Monumenta Nipponica, vol. 36, n. 3, pp. 235-284. Tôkyô, Sophia University Press, 1981.

De BARY WM, Theodore. East Asian Civilizations - a Dialogue in Five Stages (Civilizações da Ásia Oriental - um Diálogo em Cinco Estágios). Londres \& Massachussetts, Harward University Press, 1988.

DEVINE, Richard. "Hirata Atsutane and Christian Sources" In Monumenta Nipponica, vol. 36, n. 1, pp. 37-54. Tôkyô, Sophia University, 1993.

Fairbank, John K.; ReISChauer, Edwin O. \& CRaIG, Albert M. East Asia: Tradition and Transformation (Ásia Oriental: Tradição e Transformação). Londres \& Massachussetts, Harward University, 1973.

KIRKWOOD, Kenneth. Renaissance in Japan - A Cultural Survey of the Seventeenth Century (Renascença no Japão - Panorama Cultural do Século XVII). Rutland, Vermont \& Tôkyô, Charles E. Tuttle Co. Publishers, 1970.

LehmanN, Jean-Pierre. The Roots of Modern Japan (As Raizes do Japão Moderno). New York, St. Martin's Press, 1982. 
MORIYA, Takeshi. Genroku Bunka - Yûgei, Akusho, Shibai (A Cultura de Genroku - Entretenimentos, Lugares Maus, Teatro). Tôkyô, Yabundô, 1986.

MAKото, Kurozumi. "The Nature of Early Tokugawa Confucianism" ("A Natureza do Confucionismo no Início da Era Tokugawa"). Tradução e Introdução de Herman Ooms. In The Journal of Japanese Studies, vol. 20, n. 2. Seattle, University of Washington, 1994.

NAJITA, Tetsuo \& SCHEINER, Irwin (eds.). Japanese Thought in the Tokugawa Period 1600-1868 - Methods and Metaphors (O Pensamento Japonês no Período Tokugawa 1600-1868 Métodos e Metáforas). Chicago \& Londres, The University of Chicago Press, 1978.

NAJITA, Tetsuo. Kaitokudô: Visions of Virtue in Tokugawa Japan (Kaitokudô: Visões da Virtude no Japão dos Tokugawa). Chicago \& Londres, The University of Chicago Press, 1987.

NAKANE, Chie \& ÔISHI, Shinzaburô (eds.). Tokugawa Japan - The Social and Economic Antecedents of Modern Japan (Periodo Tokugawa - Antecedentes Sociais e Econômicos do Japão Moderno). Tradução Conrad Totman. Tokyo, University of Tokyo Press, 1990.

Nosco, Peter (ed.). Confucianism and Tokugawa Culture (Confucionismo e a Cultura Tokugawa). New Jersey, Princeton University Press, 1984.

ROBERTSON, Jennifer. "Rooting the Pine: Shingaku Methods of Organization" In Monumenta Nipponica, vol. 36, n. 3, pp. 311-332. Tôkyô, Sophia University, 1986.

Toвy, Ronald P. "Carnival of the Aliens: Korean Embassies en Edo-Period Art and Popular Culture”. In Monumenta Nipponica, vol. 41, n. 4, pp. 415-456. Tôkyô, Sophia University, 1986.

Totman, Conrad D. Politics in The Tokugawa Xogunato 1600-1843 (A Política no Xogunato Tokugawa 1600-1843). Cambridge, Massachusetts, Harvard University Press, 1967.

"Tokugawa Peasants: Win, Lose or Draw?" (“Os Camponeses na Era Tokugawa: Vencer, Perder ou Desistir?"). In Monumenta Nipponica, vol. 41, n. 4, pp. 457-476. Tôkyô, Sophia University, 1986.

VAPORIS, Constantine N. "Post Station and Assisting Villages: Corvée Labor and Peasant Contention". In Monumenta Nipponica, vol.41, n. 4, pp. 377-414. Tôkyô, Sophia University, 1986.

VARNER, Richard E. "The Organized Peasant: The Wakamonogumi in the Edo Period" "Camponeses Organizados: Os Wakamonogumi no Período Edo"). In Monumenta Nipponica, vol. 32, n. 4. Tôkyô, Sophia University Press, 1977.

LIDIN, Olof G. "Ogyû Sorai's Civil Society (Seidan)". In Nichibunken Japan Review, n. 5. Kyôto, International Research for Japanese Studies, 1994, pp. 3-14.

UNO, Seiichi (ed.). "Studies on Sung-Ming Neo-Confucionism" ("Estudos sobre o Neoconfucionismo das Dinastias Sung e Ming"). In Acta Asiatica, Bulletin of The Institute of Eastern Culture, n. 52. Tôkyô, The Tôhô Gakkai, 1987.

Walthall, Anne. "Peripheries: Rural Culture in Tokugawa Japan" ("Periferias: A Cultura Rural no Japão da Era Tokugawa"). In Monumenta Nipponica, vol. 39, n. 4, pp. 293-314. Tôkyô, Sophia University, 1984.

YAMASHITA, Samuel Hideo. "Reading the New Tokugawa Intellectual Histories" ("Lendo as Novas Histórias Intelectuais do Período Tokugawa”). In The Journal of Japanese Studies, vol. 22, n. 1. Seattle, University of Washington, 1996. 